\title{
PENDIDIKAN DAN PELATIHAN PENJERNIHAN AIR WADUK GUMINING MENGGUNAKAN METODE KOAGULASI, FLOKULASI DAN FILTRASI DI DESA GUMININGREJO KECAMATAN TIKUNG KABUPATEN LAMONGAN
}

\author{
Mimatun Nasihah ${ }^{1}$, Anggreani Ayu Saraswati², Sayyidatun Najah² \\ ${ }^{1}$ Dosen Kesehatan Lingkungan, Fakultas Ilmu Kesehatan, Universitas Islam Lamongan \\ ${ }^{2,3}$ Mahasiswa Kesehatan Lingkungan, Fakultas Ilmu Kesehatan, Universitas Islam Lamongan \\ Jl. Veteran No. 53 A Lamongan \\ $\underline{\text { mima@unisla.ac.id }}^{1}, \underline{\text { anggreanisaras@gmail.com }}^{2}$, sayyidatunnajah24@gmail.com $^{3}$
}

\begin{abstract}
ABSTRAK
Desa Guminingrejo adalah salah satu desa yang berada di sebelah selatan Kabupaten Lamongan. Desa Guminingrejo memiliki waduk yang terkenal dengan nama waduk gumining. Waduk ini dimanfaatkan masyakat untuk memenuhi banyak kebutuhan hidup mereka. Kualitas air waduk saat ini sudah dalam kondisi tercemar. Hasil observasi yang dilakukan pada air waduk gumining dan hasil wawancara dengan masyarakat diketahui bahwa waduk ini dimanfaatkan untuk kebutuhan minum, mandi, mencuci dan juga kebutuhan untuk pertanian. Besarnya aktivitas di sekitar waduk membuat air waduk tercemar dan berada di bawah baku mutu air kelas II, sehingga perlu dilakukan pengolahan. Dari permasalahan diatas perlu diberikan alternatif solusi yakni melalui kegiatan pengabdian masyarakat berupa pendidikan dan pelatihan penjernihan air waduk dengan menggunakan metode koagulasi, flokulasi dan filtrasi. Rencana kegiatan ini dilaksanakan dalam kegiatan pengabdian masyarakat Program Kemitraan Masyarakat (PKM) ini adalah membentuk kelompok masyarakat Peduli Air Bersih, memberikan pendidikan dan pelatihan tentang upaya penjernihan air dengan menggunakan metode koagulasi flokulasi dan filtrasi, membantu masyarakat dalam menjernihkan air untuk memenuhi kebutuhan sehari-hari. Hasil dari kegiatan ini adalah masyarakat sangat antusias dengan pelaksanaan kegiatan penjernihan air waduk gumining. Air yang dihasilkan dari proses penjernihan menjadi jernih dan tidak berbau dengan $\mathrm{pH}$ normal yakni 7.
\end{abstract}

Kata kunci: Air Waduk, Penjernihan air, Metode Koagulasi, Flokulasi dan Filtrasi

\begin{abstract}
Guminingrejo village is one of the villages in the south of Lamongan Regency. Guminingrejo village has a reservoir known as the gumining reservoir. This reservoir is usually used by the community to fulfill their daily needs. The results of observations made on the gumining reservoir water and from the results of interviews with the community can be seen that the reservoir is used for drinking, bathing, washing and also for agriculture. The amount of activity around the reservoir makes the reservoir water polluted and is below the class II water quality standard, so it needs to be management. From the above problems, it is necessary to provide alternative solutions through community devotion activities in the form of education and training in reservoir water purification using coagulation, flocculation and filtration methods. The plan of this activity is devotion community service activities. The Community Partnership Program (PKM) is forming a Clean Water Concerned community group, providing education and training on water purification efforts using flagulation and filtration coagulation methods, helping the community in purifying water to meet their daily needs. The result of this activity was that the community was very enthusiastic to the implementation of the gumining reservoir water purification. The water produced from the purification process becomes clear and odorless with a normal $\mathrm{pH}$ of 7
\end{abstract}

Keywords: Reservoir Water, Water Purification, Coagulation Method, Flocculation and Filtration 


\section{PENDAHULUAN}

Air merupakan kebutuhan dasar manusia. Sudah menjadi anggapan umum di mana kita menemukan air, maka di sana ada harapan akan kehidupan. Di Bumi, badan air terbesar terdapat di laut sebesar 97 persen dan sisanya sebesar 3 persen adalah air tawar yang kita digunakan untuk menunjang kehidupan sehari-hari. Dari air tawar itu dua per tiga nya adalah gletser dan es di kutub yang berfungsi menstabilkan iklim global dan hanya satu pertiganya saja yang dapat dimanfaatkan 7 milyar jiwa manusia di dunia (WWF, 2012). Air tawar adalah hal yang paling penting untuk kesejahteraan kita. Seperti mesin raksasa atau darah di tubuh kita, air bekerja siang dan malam. Siklus air dan ekosistem yang melekat adalah faktor utama bagi kehidupan planet ini. Dalam kehidupan manusia air tawar digunakan untuk minum, mengolah makanan, mandi, energi, transportasi, pertanian, industri, dan rekreasi.

Desa Gumingrejo merupakan salah satu desa yang secara geografis berada disebelah selatan kota Lamongan. Desa ini berada di Kecamatan Tikung, berbatasan sebelah timur dengan desa Jotosanur, sebelah selatan dengan desa Bakalanpule, sebelah Barat dengan berbatasan dengan kecamatan Kembangbahu dan sebelah utara dengan kecamatan Lamongan. Desa Gumining Rejo mempunyai 3 dusun yakni dusun Gumining, dusun Bogo dan dusun Bajangan. Kebutuhan air di Desa Gumingrejo, seperti layaknya desa-desa yang lain sangat krusial untuk memenuhi kebutuhan sehari-hari, mulai dari kebutuhan minum, mandi, mencuci, bahkan untuk kebutuhan pengairan sawah, karena penduduk desa Guminingrejo mayoritas bekerja sebagai petani. Sementara untuk memenuhi kebutuhan air tersebut, penduduk desa guminingrejo memanfaatkan air hujan, air tanah dan air waduk. Sumber air hujan hanya bisa digunakan untuk memenuhi kebutuhan saat musim hujan saja, sementara air bawah tanah yang dimanfaatkan penduduk dengan cara di bor ternyata tidak semua airnya tawar, sebagian justru sumber air bawah tanah tersebut adalah air asin, sehingga mau tidak mau keberadaan waduk menjadi sangat penting untuk kelangsungan hidup masyarakat desa guminingrejo.

Waduk Gumining merupakan waduk alami yang berada di desa guminingrejo tepatnya di daerah dusun gumining. Waduk gumining merupakan waduk alami yang ukurannya lebih kecil daripada waduk joto yang keberadaanya disebelah timur agak keselatan dari waduk gumining ini. Waduk ini dinamakan sebagai waduk gumining, diambil dari nama salah satu dusun dari desa guminingrejo yakni dusun gumining, hal ini juga dimaksudkan 
karena waduk ini berada didaerah dusun gumining sehingga masyarakat kemudian akrab dengan nama waduk gumining.

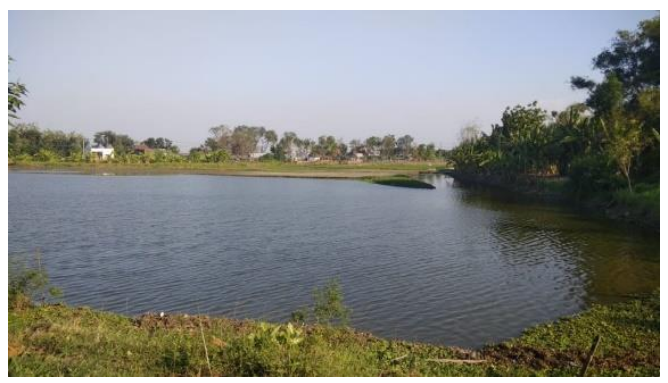

Gambar 1. Waduk Gumining

Gambar diatas menunjukan kondisi waduk pada musim kemarau. Dengan kondisi air yang mulai menyusut, waduk ini juga tidak terlalu bersih jika digunakan untuk mandi dan mencucui pakaian. Pada musim penghujan debit air waduk naik, akan tetapi warna airnya lebih keruh karena tercampur dengan tanah. Air waduk gumining ini dimanfaatkan oleh warga untuk minum, mandi, mencuci dan lain-lain dalam pengelolaan dan pengawasan pengurus HIPPAM (Himpunan Penduduk Pemakai Air Minum). HIPPAM merupakan wadah atau lembaga yang sah menurut perundang-undangan dan peraturan pemerintah untuk menyelenggarakan dan mengolah system penyediaan air bersih demi kepentingan masyarakat (http://tirtalestari-hippam.blogspot.com; 2012).

Pengurus HIPPAM terdiri dari ketua, sekretaris, bendahara, dan badan pengawas yang langsung di SK oleh Kepala Desa, pemilihan dilakukan secara musyawarah langsung dari warga masyarakat. Lembaga ini bersifat social oriented dengan tujuan untuk membantu memberikan solusi terhadap air minum bagi masyarakat. Sejauh ini pengurus HIPPAM membuat alat penampung air di tepi sebelah selatan dari waduk, kemudian air tampungan ini dialirkan ke warga-warga menggunakan pipa yang sudah dipasang, dan warga harus mebayar setiap bulan dengan besaran sesuai deng an pengeluaran air dan dengan besaran yang sudah disepakati oleh warga dengan pemerintah desa guminingrejo.

Akan tetapi masyarakat menggunakan air dari waduk gumining untuk kebutuhan mandi, mencuci dan keperluan lain selain minum. Untuk kebutuhan minum, warga membeli air minum kemasan karena kondisi air gumining tidak cukup bersih dan jernih untuk diminum.

\section{METODE}

Upaya untuk menyelesaikan permasalahan tersebut adalah dengan memberikan pengetahuan dan juga ketrampilan kepada masyarakat Gumining tentang upaya penjernihan air waduk gumining melalui metode koagulasi, flokulasi dan filtrasi. Hal ini sangat perlu 
dilakukan agar supaya masyarakat mempunyai pemahaman tentang pentingnya air bersih untuk memenuhi kebutuhan sehari-hari, selain itu masyarakat juga mempunyai ketrampilan dalam melakukan penjernihan air waduk secara sederhana namun dapat menghasilkan air yang jernih dan sehat. Metode ini cukup sederhana dan bisa dilakukan oleh semua kalangan masyarakat, mudah dan juga murah, alat dan bahan yang digunakan juga bisa didapat dengan mudah dan murah. Selain itu juga menghasilkan air yang jernih. Cara-cara yang disajikan dapat digunakan di desa karena bahan dan alatnya mudah didapat. Bahan-bahannya anatara lain batu, pasir, kerikil, arang tempurung kelapa, arang sekam padi, tanah liat, ijuk, kaporit, kapur, tawas, biji kelor dan lain-lain.

\section{Metode Koagulasi, Flokulasi dan Filtrasi}

Koagulasi merupakan metode yang digunakan untuk pengolahan air. Koagulasi menurut Metclaf (2004) adalah proses mendestabilisasi partikel koloid sehingga dapat terbentuk flok-flok halus. Koagulan yang umum digunakan adalah polialuminium klorida (PAC). Proses koagulasi bertujuan agar padatan yang tersuspensi/koloid dalam air tersebut dapat dipisahkan dengan memperbesar diameter partikel tersuspensi. Sedangkan ukuran padatan tersuspensi akan mempengaruhi terhadap proses pemisahanya (Yusuf; 2016)

Koagulan adalah zat yang ditambahkan untuk proses koagulasi (proses mendestabilisasi partikel koloid sehingga dapat terbentuk flok-flok halus). Sedangkan flokulan ditambahkan untuk meningkatkan proses flokulasi (proses pembesaran ukuran flok). Flokulasi adalah proses peningkatan ukuran partikel sebagai akibat tubrukan antar partikel. Flokulasi dibedakan menjadi:

1. Mikroflokulasi (flokulasi perikinetik) terjadi ketika partikel teragregasi karena gerakan termal acak dari molekul-molekul cairan yang disebut Brownian Motion.

2. Makroflokulasi (flokulasi ortokinetik) terjadi karena pengendapan diferensial, yaitu ketika partikel-partikel besar menarik partikel-partikel kecil membentuk partikel-partikel yang lebih besar. Makroflokulasi belum efektif sampai partikel-partikel koloid mencapai ukuran 1-10 $\mu \mathrm{m}$ melalui kontak yang didorong oleh gerak Brown dan pengadukan lambat (https://bisakimia.com/2014/12/17/penjernihan-air/; 2014)

Selain menggunakan metode koagulasi flokulasi proses penjernihan air juga dikombinasikan dengan metode filtrasi. Konsep dasar darfi pengolahan air dengan cara penyaringan adalah memisahkan padatan atau koloid dari air dengan menggunakan alat penyaring atau saringan. Air yang mengandung padatan, dilewatkan pada media saring 
dengan ukuran pori-pori atau lubang tertentu. Ukuran pori atau lubang saringan harus lebih kecil dari ukuran bahan padatan yang akan dipisahkan.

Pada proses pengolahan air minum penyaringan air ini bisa merupakan tahap awal atau tahap lanjutan. Pada pengolahan tertentu, penyaringan dilakukan setelah proses koagulasi. Untuk bahan padat yang berukuran besar, dapat disaring dengan menggunakan saringan kasar atau sedang menggunakan pasir kasar pada proses penyaringan awal. Bahan padat yang berukuran sangat kecil, atau sangat halus dan yang terlarut, mungkin akan lebih baik jika dlkakukan proses koagulasi terlebih dahulu. Hasil proses koagulasi merupakan endapan berukuran relative besar baru kemudian dilakukan penyaringan untuk memisahkan produk koagulan dari air. (https://ardra.biz/sain-teknologi/ilmu-dan-teknologiterapan/pengolahan-air-minum-dengan-penyaringan-filtrasi/)

Penjernihan air ini memakai teknologi penjernihan dengan cara kimia dan proses penyaringan. Bahan kimia yang digunakan adalah kaporit, bubuk kapur dan tawas. Bahanbahan ini mudah didapat di daerah pedesaan atau kota-kota kecil di seluruh Indonesia. Bahan penyaring yang dibutuhkan adalah kerikil, pasir, ijuk dan arang aktif.

\section{Bahan dan Peralatan}

1. 2 (dua) $\mathrm{kg}$ arang aktif

2. 3 (tiga) kg ijuk

3. Pasir halus

4. Batu kerikil

5. Bubuk kapur 10 gram

6. Tawas 10 gram

7. Kaporit 2,5 gram

8. 2 (dua) buah drum bekas

9. 2 (dua) buah kran ukuran $1 / 2 \mathrm{~cm}$

\section{Pembuatan Alat}

1. Langkah pertama adalah melubangi kedua drum $5 \mathrm{~cm}$ dari bagian bawah, dan memberi kran. Drum I untuk bak pengendapan, drum II untuk bak penyaring.

2. Meletakkan drum I lebih tinggi dari drum II hubungkan kedua drum tersebut (lihat gambar) 
3. Mengisi drum II (bak penyaringan) berturut-turut dengan batu kerikil setebal $5 \mathrm{~cm}$; arang setebal $5 \mathrm{~cm}$; ijuk setebal $5 \mathrm{~cm}$ dan pasir halus setebal $15 \mathrm{~cm}$ (lihat Gambar 1 dibawah)

4. Mengisi drum I (bak pengendapan) dengan air yang akan dijernihkan. Bubuhi dengan 10 gram tawas (untuk 100 liter air) kemudian aduk selama 5 menit. Tambahkan bubuk kapur sebanyak 10 gram dan kaporit 2,5 gram, kemudian aduk perlahan-lahan selama 2-3 menit. Tujuan mengaduk, agar butir-butir lumpur menjadi besar dan mengendap.

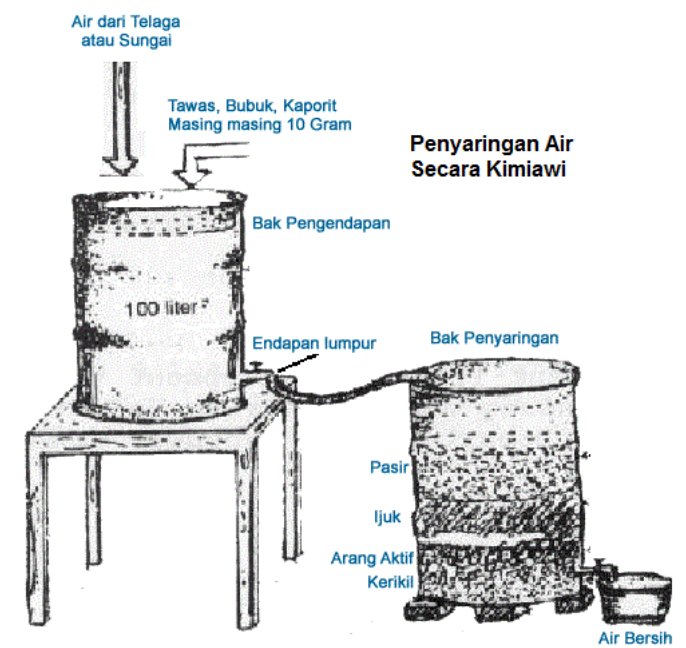

Gambar 2.Penjernihan Air Metode Koagulasi, Flokulasi dan Filtrasi

\section{Jadwal Pelaksanaan}

Tabel 1. Jadwal Pelaksanaan Pengabdian Masyarakat

\begin{tabular}{|c|c|c|c|c|}
\hline \multirow{2}{*}{ No } & Jenis Kegiatan & \multicolumn{2}{|c|}{ Waktu Pelaksanaan } \\
\cline { 3 - 4 } & Persiapan Penentuan Judul Pengabdian \\
Masyarakat & & & \\
\hline 2 & Observasi Lapangan & & & \\
\hline 3 & Wawancara dengan Masyarakat Sekitar & & & \\
\hline 4 & $\begin{array}{c}\text { Penentuan Metode Pengabdian } \\
\text { Masyarakat }\end{array}$ & & & \\
\hline 5 & Pelaksanaan Pengabdian Masyarakat & & & \\
\hline 6 & $\begin{array}{c}\text { Evaluasi Hasil Kegiatan Pengabdian } \\
\text { Masyarakat }\end{array}$ & & & \\
\hline
\end{tabular}

\section{Waktu dan Tempat Pelaksanaan}

Pengabdian Masyarakat ini dilakasanakan di Desa Guminingrejo Kecamatan Tikung Kabupaten Lamongan, pada hari kamis, tanggal 1 Agustus 2019. 


\section{HASIL DAN PEMBAHASAN}

\section{Survey dan Observasi Lapangan}

Kegiatan pengabdian masyarakat ini diawali dengan kegiatan survey lokasi terlebih dahulu. Selanjutnya melakukan wawancara dengan perangkat desa, pengurus HIPPAM dan masyarakat. Dari hasil wawancara dengan perangkat desa dalam hal ini kepala desa secara langsung, beliau mengatakan bahwa air bersih adalah kebutuhan warga dan saat ini di desa Guminingrejo menjadi keresahan tersendiri karena kondisi air Waduk tidak memenuhi syarat sebagai air bersih, padahal penduduk memanfaatkan air waduk tersebut untuk memenuhi kebutuhan sehari-hari. Kepala desa sangat berharap bahwa Universitas Islam Lamongan dalam hal ini Fakultas Ilmu Kesehatan bisa menjadi partner yang baik bagi desa Guminingrejo dan bisa membantu menyelesaikan masalah yang terjadi di desa tersebut.

Wawancara selanjutnya kami lakukan dengan Pengurus HIPPAM Desa Guminingrejo, dari hasil wawancara kami diperoleh beberapa informasi tentang upaya pengurus HIPPAM dalam mengalirkan air Waduk kepada masyarakat desa, yakni dilakukan dengan membangun alat penampungan air di dekat waduk kemudian air di salurkan ke desa menggunakan pipa. Pengurus HIPPAM mengakui bahwa alat yang digunakan untuk menampung air hanya berfungsi menampung saja, tidak ada filtrasi sehingga kondisi air ketika sampai ke rumah penduduk kondisinya masih sama seperti air di waduk. Seperti kita lihat secara langsung bahwa air waduk gumining berwarna hijau agak kecoklatan pada musim kemarau dengan bau yang tidak sedap.

Selanjutnya kami melakukan wawancara dengan beberapa penduduk yang memanfaatkan air waduk untuk kebutuhan sehari-hari. Penduduk menjelaskan bahwa air waduk hanya digunakan untuk mandi, mencuci dan menyiram bunga saja, untuk kebutuhan makan dan minum menggunakan air isi ulang, meski demikian warga mengeluhkan tentang kondisi air waduk yang berwarna hijau kecoklatan dan dengan bau yang tidak sedap, akan tetapi karena tidak mempunyai pilihan lain maka penduduk masih menggunakan air waduk tersebut. Penduduk juga mengaku bahwa sampai sejauh ini belum ada dampak yang langsung dirasakan pada kesehatan tubuh mereka, tetapi mereka sangat berharap mendapatkan solusi untuk memperoleh air bersih dengan cara yang sederhana dan bisa dilakukan sendiri oleh warga. 


\section{Analisa Masalah}

Hasil observasi dan wawancara kami kemudian dikumpulkan, di analisa, dicari alternatif solusi dan diputuskan solusi untuk melakukan upaya penjernihan air waduk dan ketrampilan tersebut bisa diberikan kepada warga masyarakat sehingga warga bisa melakukan sendiri. Dan upaya yang kami lakukan adalah dengan memberikan kegiatan pendidikan dan pelatihan penjernihan air waduk gumining menggunakan metode koagulasi, flokulasi dan filtrasi. Metode ini merupakan hasil penbelitian yang sudah kita lakukan sehingga perlu untuk diaplikasikan untuk mengatasi masalah yang dialami oleh masyarakat. Selain itu metode ini kami terapkan karena mudah dilakukan, alat dan bahan yang digunakan juga ada disekitar kita dan mudah sekaligus murah untuk didapatkan.

Selanjutnya kami melakukan koordinasi kembali dengan kepala desa Gumingrejo dan perangkatnya untuk memaparkan program yang akan kita berikan kepada masyarakat. Sekaligus menenentukan waktu dan tempat untuk melakukan kegiatan pengabdian masyarakat ini. Sasaran dan jumlah peserta juga kita tentukan bersama dengan persetujuan kepada desa, hal ini kami lakukan karena kepala desa jauh lebih memahami kebutuhan penduduknya dan siapa saja yang harus mendapatkan pelatihan ini.

\section{Kegiatan Pengangabdian Masyarakat}

Kegiatan pengabdian masyarakat ini kita konsep dalam tiga kegiatan utama yakni pemaparan materi, demonstrasi dan uji coba dari peserta, agar masyarakat tidak hanya sekedar mengetahui saja akan tetapi juga memahami sekaligus memiliki ketrampilan dalam melakukannya. Untuk mengetahui sejauh mana kemampuan masyarakat, maka kami melakukan uji pemahaman dan uji ketrampilan pra kegiatan dan pasca kegiatan pendidikan dan pelatihan. Hal ini bertujuan sebagai parameter keberhasilan kegiatan yang akan kita lakukan.

Adapun Hasil Dari Pengujian Parameter Fisik Air Waduk Guminingrejo:

\begin{tabular}{|c|l|l|}
\hline No & Hasil Air Sebelum Ditreatment & Hasil Air Sesudah Ditreatment \\
\hline 1 & & \\
& \\
& & \\
& $\begin{array}{l}\text { Air diatas menunjukkan kondisi } \\
\text { air yang dari segi fisik belum } \\
\text { jernih }\end{array}$ & $\begin{array}{l}\text { Hasil dari air waduk yang sudah } \\
\text { ditreatment menunjukkan air sudah } \\
\text { jernih }\end{array}$ \\
\hline
\end{tabular}




\begin{tabular}{|c|c|c|}
\hline No & Hasil Air Sebelum Ditreatment & Hasil Air Sesudah Ditreatment \\
\hline 2 & & \\
\hline & $\begin{array}{l}\text { Air diatas menunjukkan kondisi } \\
\text { air yang berwarna kekuningan dan } \\
\text { berbau }\end{array}$ & $\begin{array}{l}\text { Hasil dari air waduk yang sudah } \\
\text { ditreatment menunjukkan air tersebut } \\
\text { sudah tidak berbau }\end{array}$ \\
\hline
\end{tabular}

Berdasarkan hasil pengujian parameter fisik air waduk, maka pencemaran yang terjadi di beberapa sampel air waduk tersebut tergolong pencemaran ringan karena berdasarkan indikator tidak menunjukkan ciri air yang tercemar berat. Pengukuran parameter fisik menunjukkan bahwa sungai ketapang dan sungai bengawan kali mati mengalami pencemaran sedang dengan kriteria kekeruhan air dibandingkan kedua tempat lainnya.

Air merupakan pelarut yang baik, sehingga air di alam tidak pernah murni akan tetapi selalu mengandung berbagai zat terlarut maupun zat tidak terlarut serta mengandung mikroorganisme atau jasad renik. Apabila kandungan berbagai zat maupun mikroorganisme yang terdapat di dalam air melebihi ambang batas yang diperbolehkan, kualitas air akan terganggu, sehingga tidak bisa digunakan untuk berbagai keperluan baik untuk air minum, mandi, mencuci atau keperluan lainya. Air yang terganggu kualitasnya ini dikatakan sebagai air yang tercemar.

Kelarutan oksigen $(\mathrm{O} 2)$ dalam air sangat dipengaruhi oleh temperatur, tekanan, udara dan gerak pada air (turbulensi). Oksigen yang terdapat dalam air ini sangat diperlukan untukkehidupan tumbuh-tumbuhan dan hewan air. Oksigen diperlukan oleh semua mahluk yanghidup di air seperti ikan, udang, kerang dan hewan lainnya termasuk mikroorganisme seperti bakteri. Kadar oksigen dalam air juga tergantung pada kotornya air itu. Makin kotor air, maka makin kecil kadar oksigennya. Oleh karena itu oksigen juga sering dipakai sebagai parameter untuk menentukan tingkat pencemaran pada air, khususnya untuk air limbah. Untuk keperluanair minum dan kehidupan aquatik, makin tinggi kadar oksigennya makin baik air tersebut.

\section{Evaluasi dan Follow Up}

Setelah kegiatan pendidikan dan pelatihan dilaksanakan, maka kegiatan selanjutnya adalah evaluasi dan follow up. Kegiatan ini kami lakukan untuk mengetahui sejauh mana keberhasilan dan kebermanfaatan dari kegiatan yang kami lakukan kepada masyarakat. 
Follow up atau upaya tindak lanjut perlu kami lakukan untuk mengetahui sejauh mana perubahan pola sikap, pola perilaku sekaligus tingkat kesehatan masyarakat, jika masih ada kekurangan dan kelemahan maka follow up bisa digunakan untuk mencari dan menemukan alternatif solusi yang lain.

\section{Partisipasi Mitra}

Mitra dalam hal ini adalah Perangkat Desa, pengurus HIPPAM dan perwakilan masyarakat Guminingrejo. Peran serta mitra adalah sebagai peserta aktif yang berperan secara langsung maupun tidak langsung dalam proses kegiatan pengabdian masyarakat ini. Perangkat Desa dalam hal ini Kepala Desa dan perangkatnya memberikan perijinan terkait dengan pelaksanaan kegiatan pengabdian masyarakat ini, selain itu juga menyediakan tempat untuk kegiatan pengabdian masyarakat. Pengurus HIPPAM berpasrtisipasi secara aktif sejak awal proses pengumpulan data lapangan yang kami lakukan, pengurus HIPPAM memberikan informasi fakta tentang kondisi air waduk gumining dan bagaimana masyarakat mengalami kendala dalam menggunakanya, selain itu pengurus HIPPAM juga merupakan peserta aktif yang akan membantu menggerakkan masyarakat dalam upaya perwudujan mendapatkan air bersih di Desa Guminingrejo. Adapun masyarakat secara luas berperan sebagai peserta kegiatan kami yang akan mendapatkan ilmu sekaligus ketrampilan secara langsung tentang langkah-langkah penjernihan air untuk mendapatkan air bersih untuk selanjutnya akan diaplikasikan di tingkat rumah tangga masing-masing.

\section{Evaluasi}

Kegiatan Pengabdian Masyarakat ini kita awali dengan penandatangan MoU antara Perguruan Tinggi dengan Pemerintah Desa Guminingrejo dalam kurun waktu 3 tahun sejak tahun 2019 hingga tahun 2022. MoU ini merupakan bukti sah bahwa Desa Guminingrejo merupakan desa binaan dari Perguruan Tinggi Universitas Islam Lamongan sehingga program Pengabdian Masyarakat ini tidak hanya merupakan kegiatan insidentil yang akan selesai begitu saja ketika kegiatan pengabdian selesai, akan tetapi akan terus kita evaluasi dan follow up keberhasilan dari kegiatan pengabdian masyarakat kami. Indikator keberhasilan dapat dilihat dengan adanya perubahan pola pikir, pola perilaku dan pola kebiasaan masyarakat. Selain itu indikator yang lain ditunjukan dengan adanya air bersih yang dibisa diakses dengan mudah oleh masyarakat desa Guminingrejo dan dalam jangka panjang tingkat kesehatan masyarakat dapat meningkat. 


\section{SIMPULAN}

Dari hasil pendidikan dan pelatihan yang telah dilakukan dapat disimpulkan bahwa di Desa Guminingrejo masih kurangnya kesadaran warga tentang pentingnya penjernihan air waduk yang baik dan benar dengan cara mengunakan metode koagulasi-flokulasi dan filtrasi untuk mengurangi masalah yang ada pada air waduk.

\section{DAFTAR PUSTAKA}

Anonim, 2013, "Penjernihan Air Sederhana" Sumber http://kimiasekali.blogspot.com/2013/06/penjernihan-air-sederhana.html

Bululengky, 2014, "Penjernihan Air” sumber (https://bisakimia.com/2014/12/17/penjernihanair/;)

Hippam Tirta Lestari: 2014. Sumber (http://tirtalestari-hippam.blogspot.com;).

Menteri Negara Riset dan Teknologi, "Penjernihan Air Dengan Cara Penyaringan Dan Bahan Kimia" Sumber : http://www.iptek.net.id/ind/warintek/?mnu=6\&ttg=5\&doc=5b3

Pengolahan Air Minum dengan Penyaringan, Filtrasi. Sumber (https://ardra.biz/sainteknologi/ilmu-dan-teknologi-terapan/pengolahan-air-minum-dengan penyaringan$\underline{\text { filtrasi/ }}$

WWF, 2012, "Air Bersih dan Kehidupan Manusia" Sumber https://www.wwf.or.id/?26120/Air-Bersih-dan-Kehidupan-Manusia 